Scientia Agricola

http://dx.doi.org/10.1590/0103-9016-2015-0096

\title{
Sensory and physicochemical characteristics of low sodium salami
}

\author{
Marcio Aurelio de Almeida ${ }^{1}$, Nilda Doris Montes Villanueva², Jair Sebastião da Silva Pinto ${ }^{1}$, Erick Saldaña ${ }^{1}$, Carmen J. Contreras- \\ Castillo ${ }^{1 *}$
}

\author{
'University of São Paulo/ESALQ - Dept. of Agro-industry, \\ Food and Nutrition, Av. Pádua Dias, 11 - 13418-900 - \\ Piracicaba, SP - Brazil. \\ ${ }^{2}$ Catholic University "Sedes Sapientiae"/FIA, Esq. \\ Constelaciones y Sol de Oro, s/n - Urbanización Sol de Oro, \\ Los Olivos - Lima - Peru. \\ *Corresponding author <ccastill@usp.br>
}

Edited by: Luís Guilherme de Lima Ferreira Guido

Received April 13, 2015

Accepted October 20, 2015

\begin{abstract}
The aim of the present study was to develop low sodium salami prepared with pork, low-fat beef and a small quantity of pork back fat $\left(150 \mathrm{~g} \mathrm{~kg}^{-1}\right)$. Sodium chloride ( $\left.\mathrm{NaCl}\right)$ was replaced by potassium chloride $(\mathrm{KCl})$ and calcium chloride $\left(\mathrm{CaCl}_{2}\right)$, and salamis were tasted to obtain low-salt salami with sensory characteristics similar to those found in commercial ones. Salamis were prepared following seven different treatments. Treatments included five different combinations of $\mathrm{KCl}$ and $\mathrm{CaCl}_{2}$ which varied from $5 \mathrm{~g} \mathrm{~kg}^{-1}$ to $10 \mathrm{~g} \mathrm{~kg}^{-1}$ and two controls containing high $\left(25 \mathrm{~g} \mathrm{~kg}^{-1}\right)$ and low $\left(10 \mathrm{~g} \mathrm{~kg}^{-1}\right)$ concentrations of $\mathrm{NaCl}$. The right level of saltiness of each treatment was evaluated on "just-about-right" (JAR) scales and analyzed by Penalty Analysis. The results showed differences in $\mathrm{pH}$ and $\mathrm{Aw}$ (water activity) due to $\mathrm{NaCl}$ reduction. Salt replacement mixtures of $\mathrm{KCl} / \mathrm{CaCl}_{2}$ in salamis did not affect this process technologically (slicing, appearance and texture), and the decrease in Na content was approximately $55 \%$. Although no significant differences were observed in appearance, treatments differed $(p \leq 0.05)$ in flavor, texture, and overall liking. As regards salt content of salami, consumers considered treatments with low $\mathrm{NaCl}$ content and replacers $\mathrm{KCl}$ and $\mathrm{CaCl}_{2}(\% \mathrm{Na})$ as having an acceptable level of saltiness. However, this replacement produced a strange taste. Thus, the production of low sodium salamis using salt replacers $\left(\mathrm{KCl}\right.$ and $\left.\mathrm{CaCl}_{2}\right)$ or salamis without replacers with a value higher than $1 \%$ of $\mathrm{NaCl}$ can be used effectively without compromising major sensorial attributes.
\end{abstract}

Keywords: salt reducing, consumers testing, potassium chloride, calcium chloride, penalty analysis

\section{Introduction}

High intake of salt has been associated with a high risk of non-communicable diseases, including hypertension, cardiovascular disease and stroke (WHO, 2012). According to Quilaqueo et al. (2015), the main source of $\mathrm{Na}$ in diets is sodium chloride $(\mathrm{NaCl})$. In general, a traditional consumption of more than $6 \mathrm{~g}$ of $\mathrm{NaCl}$ person $\mathrm{d}^{-1}$ is associated with health problems, such as high blood pressure levels, thereby contributing to an increased risk of cardiovascular diseases in the population (Choi et al., 2014; Desmond, 2006; Ruusunen and Puolanne, 2005, WHO, 2003).

Among meat products, dry fermented sausages such as various types of salami have high added value. However, this product is an important source of $\mathrm{Na}$, since between $2-3 \%$ of $\mathrm{NaCl}$ is added during its preparation. After dehydration, $\mathrm{NaCl}$ concentration usually increases from 3 to $5 \%$ (Cichoski et al., 2011; Toldrá, 2007).

It is during the preparation phase of salami that most physical and biochemical changes occur, the fractions of sarcoplasmic proteins begin a denaturing process, which influence the solubilization of myofibrillar proteins, actin and myosin in meat. These biochemical changes occur at the end of the drying and at the beginning of the ripening process, and contribute to firmness consistency and appropriate sliceability of the product (Beriaín et al., 1993; Buckenhüskes, 1993).

The sensory quality of low sodium salami developed in this research includes different sensory attributes such as appearance, flavor and texture as compared with a traditional salami. According to Fellendorf et al. (2015), the perception of saltiness has the greatest influence on sensory acceptability in this type of product (meat products with low sodium content). In order to formulate a process to reduce sodium content, saltiness can be directly related to the type of salt substitute used during formulation. JAR scales were used to assess the saltiness intensity perceived by the consumer, in terms of being above or below ideal levels for that attribute. Additionally, reduction of acceptability with saltiness perception was associated with penalty analysis (Popper, 2014). According to Agudelo et al. (2015), the penalty analysis helps to identify possible improvements in the sensory characteristics of products, by identifying ideal levels of attributes, and thereby increase their acceptability.

The aim of this study was to evaluate the effects of lower $\mathrm{Na}$ concentration and salt replacers on sensory and physicochemical characteristics including saltiness perception, and consumers'purchase intention of salami.

\section{Materials and Methods}

\section{Treatments}

Treatments were prepared with five replacement levels of $\mathrm{NaCl}$ by $\mathrm{KCl}$ mixed with $\mathrm{CaCl}_{2}$. One control was prepared with the usual level of $25 \mathrm{~g} \mathrm{~kg}^{-1} \mathrm{NaCl}(\mathrm{CH})$ and another control with the addition of $10 \mathrm{~g} \mathrm{~kg}^{-1} \mathrm{NaCl}$ (CL) without replacers (Table 1).

\section{Production process}

The raw materials used in this study were purchased from a slaughterhouse under the Government 
Table 1 - Levels of salt replacers and $\mathrm{NaCl}$ reduction in the different treatments.

\begin{tabular}{|c|c|c|c|}
\hline \multirow[b]{2}{*}{ Treatments } & \multicolumn{3}{|c|}{ Amount of salts added in $\mathrm{g} \mathrm{kg}^{-1}$} \\
\hline & $\begin{array}{l}\text { Sodium chloride } \\
\text { ( } \mathrm{NaCl})\end{array}$ & $\begin{array}{l}\text { Potassium chloride } \\
\text { (KCl) }\end{array}$ & $\begin{array}{l}\text { Calcium chloride } \\
\qquad\left(\mathrm{CaCl}_{2}\right)\end{array}$ \\
\hline $\mathrm{T} 1$ & 10.0 & 5.0 & 5.0 \\
\hline T2 & 10.0 & 4.5 & 4.5 \\
\hline T3 & 10.0 & 4.0 & 4.0 \\
\hline T4 & 10.0 & 3.5 & 3.5 \\
\hline T5 & 10.0 & 2.5 & 2.5 \\
\hline $\mathrm{CH}$ & 25.0 & 0.0 & 0.0 \\
\hline $\mathrm{CL}$ & 10.0 & 0.0 & 0.0 \\
\hline \multicolumn{4}{|c|}{$\begin{array}{l}\mathrm{T} 1-10 \mathrm{~g} \mathrm{~kg}^{-1} \mathrm{NaCl}+5 \mathrm{~g} \mathrm{~kg}^{-1} \mathrm{KCl}+5 \mathrm{~g} \mathrm{~kg}^{-1} \mathrm{CaCl}_{2} ; \mathrm{T} 2-10 \mathrm{~g} \mathrm{~kg}^{-1} \mathrm{NaCl}+4.5 \\
\mathrm{~g} \mathrm{~kg}^{-1} \mathrm{KCl}+4.5 \mathrm{~g} \mathrm{~kg}^{-1} \mathrm{CaCl}_{2} ; \mathrm{T} 3-10 \mathrm{~g} \mathrm{~kg}^{-1} \mathrm{NaCl}+4 \mathrm{~g} \mathrm{~kg}^{-1} \mathrm{KCl}+4 \mathrm{~g} \mathrm{~kg}^{-1} \\
\mathrm{CaCl}_{2} ; \mathrm{T} 4-10 \mathrm{~g} \mathrm{~kg}^{-1} \mathrm{NaCl}+3.5 \mathrm{~g} \mathrm{~kg}^{-1} \mathrm{KCl}+3.5 \mathrm{~g} \mathrm{~kg}^{-1} \mathrm{CaCl}_{2} ; \mathrm{T}-10 \mathrm{~g} \\
\mathrm{~kg}^{-1} \mathrm{NaCl}+2.5 \mathrm{~g} \mathrm{~kg}^{-1} \mathrm{KCl}+2.5 \mathrm{~g} \mathrm{~kg}^{-1} \mathrm{CaCl}_{2} ; \mathrm{CH}-25 \mathrm{~g} \mathrm{~kg}^{-1} \mathrm{NaCl} ; \mathrm{CL}-10 \\
\mathrm{~g} \mathrm{~kg}^{-1} \mathrm{NaCl} .\end{array}$} \\
\hline
\end{tabular}

Agency for Inspection of Animal Products and three production processes were carried out. The salami was prepared with pork shoulder $\left(600 \mathrm{~g} \mathrm{~kg}^{-1}\right)$, beef rib (250 $\mathrm{g} \mathrm{kg}^{-1}$ ) and pork backfat from the lumbar region (150 $\left.\mathrm{g} \mathrm{kg}^{-1}\right)$. Chilled beef and pork were pre-weighed and cut. Raw materials were ground separately in a grinder using 10,5, and $8 \mathrm{~mm}$ plates for pork, beef, and backfat, respectively. We initially added pork and beef, followed by pork back fat. After mixing the raw meat, non-meat ingredients were added $(\mathrm{NaCl})$ and other ingredients $\left(\mathrm{KCl}\right.$ and $\left.\mathrm{CaCl}_{2}\right)$ according to each treatment (Table 1).

Additionally, the following common ingredients were added to the meat mixture in each treatment: sodium nitrite $\left(0.15 \mathrm{~g} \mathrm{~kg}^{-1}\right)$ and nitrate $\left(0.15 \mathrm{~g} \mathrm{~kg}^{-1}\right)$, sodium erythorbate $\left(0.3 \mathrm{~g} \mathrm{~kg}^{-1}\right)$, condiments $\left(7.0 \mathrm{~g} \mathrm{~kg}^{-1}\right)$, dextrose $\left(0.70 \mathrm{~g} \mathrm{~kg}^{-1}\right)$, a commercial starter culture $\left(0.25 \mathrm{~g} \mathrm{~kg}^{-1}\right)$ containing Pediococcus pentosaceus and Staphylococcus xylosus. The meat batter was stuffed into reconstituted collagen casings measuring $45 \mathrm{~mm}$ in diameter. Sausages were hand-linked to standard sizes (400 g), hung from metal rods and placed in a ripening chamber at $23 \pm 1$ ${ }^{\circ} \mathrm{C}$ for $60 \mathrm{~h}$, with RH (Relative humidity) between 85 $90 \%$ to reach a pH between 4.9 - 5.2. Later, the sausages were taken to a ripening chamber at $16-18{ }^{\circ} \mathrm{C}$ and $\mathrm{RH}$ $65-75 \%$ where they remained for 26 days until water activity was $0.88-0.92$ for all treatments. Casings were removed and salamis were vacuum packed and frozen at $-25 \pm 1{ }^{\circ} \mathrm{C}$ until analysis.

\section{Experimental design}

Physicochemical data was analyzed as a completely randomized design where a batch weighing $6 \mathrm{~kg}$ was considered the experimental unit. We used three batches on different days of processing. Each treatment was processed in triplicate: T1 (treatment 1) with $10 \mathrm{~g} \mathrm{~kg}^{-1} \mathrm{NaCl}$ $+5 \mathrm{~g} \mathrm{~kg}^{-1} \mathrm{KCl}$ and $5 \mathrm{~g} \mathrm{~kg}^{-1} \mathrm{CaCl}_{2}$; $\mathrm{T} 2$ (treatment 2) with $10 \mathrm{~g} \mathrm{~kg}^{-1} \mathrm{NaCl}+4.5 \mathrm{~g} \mathrm{~kg}^{-1} \mathrm{KCl}$ and $4.5 \mathrm{~g} \mathrm{~kg}^{-1} \mathrm{CaCl}_{2}$; $\mathrm{T} 3$ (Treatment 3) - $10 \mathrm{~g} \mathrm{~kg}^{-1} \mathrm{NaCl}+4 \mathrm{~g} \mathrm{~kg}^{-1} \mathrm{KCl}+4 \mathrm{~g} \mathrm{~kg}^{-1}$ $\mathrm{CaCl}_{2}$; T4 (Treatment 4) - $10 \mathrm{~g} \mathrm{~kg}^{-1} \mathrm{NaCl}+3.5 \mathrm{~g} \mathrm{~kg}^{-1}$ $\mathrm{KCl}+3.5 \mathrm{~g} \mathrm{~kg}^{-1} \mathrm{CaCl}_{2}$; $\mathrm{T} 5$ (Treatment 5) - $10 \mathrm{~g} \mathrm{~kg}^{-1} \mathrm{NaCl}$
$+2.5 \mathrm{~g} \mathrm{~kg}^{-1} \mathrm{KCl}+2.5 \mathrm{~g} \mathrm{~kg}^{-1} \mathrm{CaCl}_{2} ; \mathrm{CH}$ (High control) - $25 \mathrm{~g} \mathrm{~kg}^{-1} \mathrm{NaCl}$; CL (Low control) - $10 \mathrm{~g} \mathrm{~kg}^{-1} \mathrm{NaCl}$. Samples of raw sausages (sausage batter) and ripening/ dry sausages were subjected to $\mathrm{pH}$, water activity, $\mathrm{Na}$ content, lipid content, moisture content and total protein content. Sensory data was analyzed as a Complete Block Design where consumers were considered blocks.

\section{Physicochemical analyses}

The $\mathrm{pH}$ was determined by a calibrated portable $\mathrm{pH}$ meter with automatic temperature compensation and an electrode with a penetration probe. The analysis was performed at the beginning of the manufacturing process (before stuffing), after fermentation (2.5 days) and at the end of processing (28 days). The samples were analyzed in triplicate per treatment to obtain mean values.

Water activity (Aw) of salami samples was determined using a $4 \mathrm{~T}$ Aqualab water activity meter at the beginning of the production process (before stuffing) and at the end of processing ( 28 days). Salami slices measuring approximately $3 \mathrm{~mm}$ thick, were placed in capsules suitable for analysis, with the exception of the raw sausage, which was spread before analysis on the bottom of the capsules.

Moisture was determined by the difference between the moist and the dry material, using a stove at $105{ }^{\circ} \mathrm{C}$, as per the AOAC methodology (2005). Total protein content was determined in accordance with the method described by Kjeldahl (AOAC, 2005): the calculation was made with the dry base and then transformed into a moist base. The determination of lipids was performed as described by Soxhlet (AOAC, 2005), with the results expressed in percentages. This analysis was conducted 28 days after the salami was processed. Three sausages per treatment were used for evaluation and each analysis was performed in triplicate.

In order to determine the sodium content in the salami, the analysis was conducted following the AOAC methodology (2005). Five grams of the sample were weighed directly on the porcelain capsule, previously heated in a muffle at $550{ }^{\circ} \mathrm{C}$, before being cooled and weighed. The capsule with the sample was carbonized on a hot plate and then calcined in a muffle at $550{ }^{\circ} \mathrm{C}$. When the capsules had cooled, the ashes were dissolved with $2.5 \mathrm{~mL}$ of nitric acid and transferred to a volumetric flask of $50 \mathrm{~mL}$. A blank sample was used as a control. The readings were recorded using a flame photometer, 28 days after the salami was processed.

\section{Consumer study}

Consumers of different ages (21 - 60 years old) and from different regions of the country were recruited in Piracicaba, SP, Brazil. The 52 consumers recruited indicated that they were regular salami consumers. The sensory analyses were designed in accordance with ISO 8589 (ISO, 2007). The consumers were placed in individual tasting booths, where they received instructions 
on the use of the scale, the nature of the products and the type of evaluation to be carried out. The seven salami samples were served in a monadic way, according to the sample presentation order, and were evaluated under white light on disposable white plates coded with random three-digit numbers. During the sensory evaluation, an interval of two hours was allowed between the $4^{\text {th }}$ and $5^{\text {th }}$ samples to avoid sensory fatigue. Mineral water and unsalted crackers were used to clear the palate between samples.

After appearance evaluation, consumers were asked to taste the product and evaluate to what extent they liked or disliked each sample in terms of texture, flavor and overall liking (OL) using a nine-point hedonic scale $(1=$ disliked extremely, $5=$ Neither liked nor disliked, 9 = extremely liked) (Meilgaard et al., 2007). Afterwards, consumers evaluated the salt content of the samples by using a Just-About-Right scale (JAR) (7 $=$ much too high, $4=$ just about right and $1=$ much too low) (Popper, 2014). Finally, consumers assessed their purchase intent to the tested products by using a five-point structured scale $(1=$ certainly will not buy, 3 = may or may not buy and $5=$ certainly will buy). This study was registered and approved by the Ethics in Research Committee of ESALQ-USP under protocol No.104/2012.

\section{Statistical analysis}

The physicochemical measurements of the experimental treatments were analyzed using analyses of variance (ANOVA) ( $p \leq 0.05$ ) considering sample and block as sources of variation. The acceptability responses of the attributes evaluated were analyzed using a three-way ANOVA ( $p \leq 0.05)$, which considered samples, consumers and presentation order of samples as sources of variation. To evaluate the differences in sensory and physicochemical characteristics between the samples, paired comparisons of the means were made using the Tukey HSD test $(p \leq 0.05)$. The physicochemical and sensory characteristics were correlated by way of partial least square (PLS) regression analysis (Cadena et al., 2013). The JAR results were analyzed by penalty analysis. The statistical data analysis was performed using the SAS
(SAS Inst., North Carolina, USA), XLSTAT (Addinsoft, New York, USA) and Statistica ${ }^{\mathrm{TM}}$ software (Statsoft Inc., Tulsa, Oklahoma, USA).

\section{Results and Discussion}

\section{Physicochemical analyses}

The physicochemical characteristics of the salamis produced with replacers of $\mathrm{NaCl}$ using $\mathrm{KCl}$ combined with $\mathrm{CaCl}_{2}$ are shown in Table 2. The Aw value before stuffing ranged from 0.96 to 0.98 , with statistically significant differences between the treatments $(p \leq 0.05)$. Treatment $\mathrm{CH}$ already showed lower Aw than the other treatments due to the higher amount of $\mathrm{NaCl}$ (approximately $55 \%$ ) in this treatment. However, this difference caused by a reduction in $\mathrm{NaCl}$ and replacers with a mixture of $\mathrm{KCl} / \mathrm{CaCl}_{2}$ in salamis did not affect the processing characteristics of the initial stage of the process.

This small difference in Aw in all treatments compared to $\mathrm{CH}$ continued to present differences throughout the fermentation, drying and ripening periods of the salami (Table 2), showing that the $\mathrm{CH}$ treatment had lower Aw values (0.89) than the other treatments. Therefore, by the end of ripening, the salamis were showing Aw values within the limits required by Brazilian law (maximum Aw 0.92). A safe range of low Aw is one of the major barriers to growth of undesirable microorganisms in the product. Thus, the treatments with reduced $\mathrm{NaCl}$ and replacers with a mixture of $\mathrm{KCl} / \mathrm{CaCl}_{2}$ were stable during salami production. The CL treatment $(10$ $\mathrm{g} \mathrm{kg}^{-1}$ ), which contains $\mathrm{NaCl}$ was on the threshold of hindering commercial production of salami (Desmond, 2006), had a lower dehydration rate and reached Aw of 0.92. On the other hand, the CL treatment had the appropriate technological characteristics.

During manufacturing, the $\mathrm{pH}$ development of all samples (Table 2) showed values between 5.9-6.0 and after fermentation ( $60 \mathrm{~h}), \mathrm{pH}$ values of the control and other treatments were below 5.0. Although rapid fermentation is desirable in salami production, in this research, we used a milder fermentation temperature and consequently a longer fermentation period. This reduction in $\mathrm{pH}(\mathrm{pH}$ lower than 5.2 with $24-60 \mathrm{~h}$ of fer-

Table 2 - Means ( \pm SD) of Aw and $\mathrm{pH}$ in experimental treatments during salami production.

\begin{tabular}{|c|c|c|c|c|c|}
\hline \multirow{2}{*}{ Treatments } & \multicolumn{2}{|c|}{ Aw } & \multicolumn{3}{|c|}{$\mathrm{pH}$} \\
\hline & Sausage batter & End ripening & Sausage Bater & After fermentation & End ripening \\
\hline $\mathrm{T} 1$ & $0.97^{a} \pm 0.002$ & $0.91^{b} \pm 0.002$ & $5.9^{a} \pm 0.04$ & $5.0^{a} \pm 0.08$ & $5.1^{a} \pm 0.08$ \\
\hline T2 & $0.97^{a} \pm 0.002$ & $0.91^{b} \pm 0.002$ & $5.9^{a} \pm 0.12$ & $5.0^{\mathrm{a}} \pm 0.11$ & $5.1^{a} \pm 0.01$ \\
\hline T3 & $0.97^{a} \pm 0.002$ & $0.91^{b} \pm 0.002$ & $5.9^{a} \pm 0.19$ & $5.0^{a} \pm 0.05$ & $5.2^{a} \pm 0.06$ \\
\hline T4 & $0.97^{a} \pm 0.002$ & $0.91^{b} \pm 0.002$ & $5.9^{a} \pm 0.26$ & $5.0^{a} \pm 0.04$ & $5.2^{a} \pm 0.10$ \\
\hline T5 & $0.97^{a} \pm 0.002$ & $0.91^{b} \pm 0.002$ & $5.8^{a} \pm 0.04$ & $5.0^{a} \pm 0.04$ & $5.2^{a} \pm 0.06$ \\
\hline $\mathrm{CH}$ & $0.96^{b} \pm 0.002$ & $0.89^{a} \pm 0.002$ & $5.9^{a} \pm 0.10$ & $5.0^{\mathrm{a}} \pm 0.05$ & $5.2^{a} \pm 0.02$ \\
\hline
\end{tabular}

Values represent the average \pm standard deviation. Averages within the same column, in the same experiment, followed by the same letters did not show any significant difference $(\mathrm{p} \geq 0.05)$ by the Tukey test. The following treatments were used: $\mathrm{T} 1-10 \mathrm{~g} \mathrm{~kg}^{-1} \mathrm{NaCl}+5 \mathrm{~g} \mathrm{~kg} \mathrm{KCl}^{-1} 5 \mathrm{~g} \mathrm{~kg} \mathrm{KCaCl}^{-1}$; $2-10 \mathrm{~g} \mathrm{~kg}-1 \mathrm{NaCl}+$ $4.5 \mathrm{~g} \mathrm{~kg}^{-1} \mathrm{KCl}+4.5 \mathrm{~g} \mathrm{~kg}^{-1} \mathrm{CaCl}_{2} ; \mathrm{T} 3-10 \mathrm{~g} \mathrm{~kg}^{-1} \mathrm{NaCl}+4 \mathrm{~g} \mathrm{~kg}^{-1} \mathrm{KCl}+4 \mathrm{~g} \mathrm{~kg}^{-1} \mathrm{CaCl}_{2} ; \mathrm{T} 4-10 \mathrm{~g} \mathrm{~kg}^{-1} \mathrm{NaCl}+3.5 \mathrm{~g} \mathrm{~kg} \mathrm{KCl}^{-1}+3.5 \mathrm{~g} \mathrm{~kg}{ }^{-1} \mathrm{CaCl} ; \mathrm{T} 5-10 \mathrm{~g} \mathrm{~kg}{ }^{-1}$ $\mathrm{NaCl}+2.5 \mathrm{~g} \mathrm{~kg}^{-1} \mathrm{KCl}+2.5 \mathrm{~g} \mathrm{~kg}^{-1} \mathrm{CaCl}_{2} ; \mathrm{CH}-25 \mathrm{~g} \mathrm{~kg}^{-1} \mathrm{NaCl} ; \mathrm{CL}-10 \mathrm{~g} \mathrm{~kg}^{-1} \mathrm{NaCl}$. 
mentation) is extremely important for fermented meat products because the lactic acid inhibits a large number of pathogenic and spoilage microorganisms, and triggers proteolysis thereby assisting at the commencement of the salami drying process. Low $\mathrm{pH}$ causes the protein to reach its isoelectric point and consequently a reduced water binding capacity, which makes it easier for salami to lose water, and thus facilitates its dehydration (Leroy et al., 2006; Toldrá et al., 2007).

During fermentation, lactic acid is produced due to the breakdown of carbohydrates by lactic acid bacteria added via commercial starter culture and natural bacterial flora. The amount of carbohydrate used 10.7 $\mathrm{g} \mathrm{kg}^{-1}$ ) was enough to produce fermentation with $\mathrm{pH}$ values near 5.0, similar to those reported by Del Nobile et al. (2009) and Lücke (1994). At the end of the ripening and manufacturing process, $\mathrm{pH}$ values increased from 5.1 to 5.3 . These values were observed in all treatments and are considered typical of salami aging due to the formation of basic compounds of non-protein nitrogen (NPN) as well as the buffering effect of the protein (Astiasarán et al., 1990).

In the current research, to decrease the impact of a reduction in $\mathrm{Na}$ on salami texture, we opted for a smaller addition of lipids, about $28 \%$, and increased the addition of lean meat to about $25 \%$, which can be proven by the high protein content in all treatments (between $31-32 \%$, values not shown). Next because of the lean meat having higher protein quantity available, there were more binding pieces of meat which were firmer in the salami. Moisture content between all treatments remained between 33 - $37 \%$. The level of moisture could also be lowered so as to promote the traditional firmness of salami that is considered ideal by consumers. In all treatments a reduction in $\mathrm{NaCl}$ and replacers with a mixture of $\mathrm{KCl} / \mathrm{CaCl}_{2}$ (T1-T5) did not affect the processing characteristics. However, certain adjustments are required for the processing, such as protein content, fat content and moisture content in order to optimize the production process of salami. All treatments have values within the limits indicated by Brazilian standards No. 22 of July 31, 2000, for salami (MAPA, 2000).

In the present study, $\mathrm{NaCl}$ replacers with different chloride salts $\mathrm{KCl}+\mathrm{CaCl}_{2}$ significantly decreased

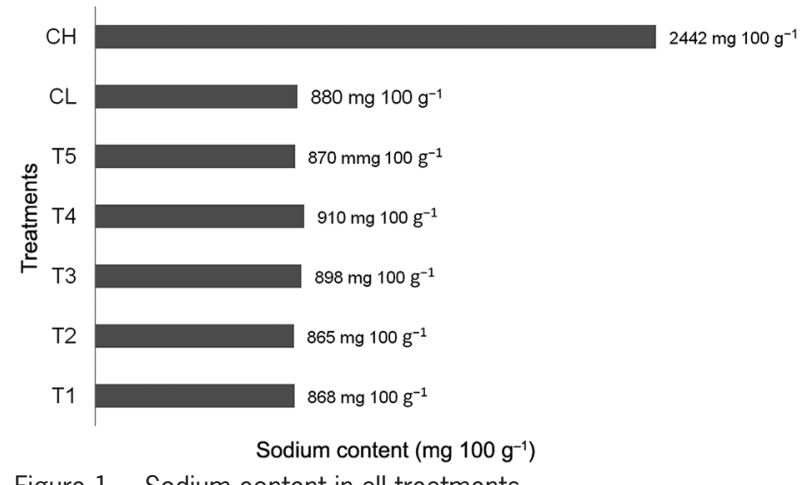

Figure 1 - Sodium content in all treatments. $(p<0.05)$ the $\mathrm{Na}$ content in products (Figure 1$)$. Treatments T1, T2, T3, T4, T5 and CL, presented Na content between 865 - $898 \mathrm{mg} 100 \mathrm{~g}^{-1}$ and treatment $\mathrm{CH}$ had $\mathrm{Na}$ content $2450 \mathrm{mg} 100 \mathrm{~g}^{-1}$. Thus, replacing $\mathrm{NaCl}$ with $\mathrm{KCl}+\mathrm{CaCl}_{2}$ resulted in an approximate $64 \%$ reduction in $\mathrm{Na}$ content. This fact is very important due to the particularities of the Brazilian market, where salami are found with an $\mathrm{Na}$ content of between 1,610 mg $100 \mathrm{~g}^{-1}$ and 2,560 $\mathrm{mg} 100 \mathrm{~g}^{-1}$. The average Brazilian consumes $3,200 \mathrm{mg} \mathrm{Na} 100 \mathrm{~g}^{-1}$ person $\mathrm{d}^{-1}$, which is higher than the maximum intake recommended by the $\mathrm{WHO}$ and the FAO (WHO, 2003). Therefore, marketing a product with low sodium content could be a good option for both the industry and consumers. Consumers are looking for more products with healthy characteristics (e.g. low fat content, without trans fat, low sodium content). Viewed from this perspective, this segment represents an important niche in the market, with potential consumers for the industry. We should also emphasize the health problems caused by high sodium intake.

However, a salt reduction at this level is considered critical because of microbial contamination or risk of hetero fermentation during the fermentation process of salami (Ruusunen and Puolanne, 2005). In this research, replacements with chloride mixtures $(\mathrm{KCl}+$ $\mathrm{CaCl}_{2}$ ) were chosen rather than a replacement of only one type of chloride. Other authors (Campagnol et al., 2012) reported that the replacement of $\mathrm{NaCl}$ by $\mathrm{KCl}(50$ $\%)$ did not result in significant changes in fermentation and dehydration of salamis. However, it did diminish the sensory quality of their salamis.

\section{Consumer study}

The ANOVA of the acceptability data showed no differences in the appearance (color) of salami (Table 3). However, there were differences $(p \leq 0.05)$ in flavor, texture and overall liking. All treatments obtained scores between 5.9 - 7.5, an acceptability average of "like slightly" to "like moderately" for all attributes.

The flavor was negatively affected by reductions in $\mathrm{NaCl}$ and replacement with mixtures of $\mathrm{KCl} / \mathrm{CaCl}_{2}$. Results showed that the addition of mixtures containing $4 \mathrm{~g} \mathrm{~kg}^{-1}$ of $\mathrm{KCl}+4 \mathrm{~g} \mathrm{~kg}^{-1}$ of $\mathrm{CaCl}_{2}$ led to detrimental effects on salami taste (Table 3). Regarding texture, consumers reported lack of consistency caused by $\mathrm{NaCl}$ reduction and the reduction of this ingredient recorded lower scores in all treatments compared to $\mathrm{CH}$. The same trend was observed in consumers OL (overall liking) who liked the treatments less with $\mathrm{NaCl}$ reduction and replacement with $\mathrm{KCl} / \mathrm{CaCl}_{2}$ compared to $\mathrm{CH}$.

This trend may be attributed to the presence of $\mathrm{KCl}, \mathrm{CaCl}_{2}$ or the mixture of these salts. They affect the activity of lipolytic enzymes, changing the flavor of fermented products. Furthermore, the addition of $\mathrm{KCl}$ and $\mathrm{CaCl}_{2}$ in meat products is limited by the bitter taste, metallic taste and astringent sensation that high concentrations of these salts provide to meat products (Blesa et al., 2008; Ripollés et al., 2011). 
Table 3 - Acceptance values of color, flavor, texture, overall acceptance, salt content, and purchase intention for seven salami formulations.

\begin{tabular}{|c|c|c|c|c|c|c|c|}
\hline Attribute & $\mathrm{CH}$ & $\mathrm{CL}$ & $\mathrm{T} 1$ & T2 & T3 & T4 & T5 \\
\hline Appearance & $7.3^{\mathrm{a}} \pm 1.2$ & $7.4^{\mathrm{a}} \pm 1.4$ & $7.0^{\mathrm{a}} \pm 1.4$ & $7.0^{\mathrm{a}} \pm 1.3$ & $7.5^{\mathrm{a}} \pm 1.1$ & $7.1^{\mathrm{a}} \pm 1.3$ & $7.3^{a} \pm 1.3$ \\
\hline Flavor & $7.2^{\mathrm{a}} \pm 1.9$ & $6.2^{\mathrm{b}} \pm 1.9$ & $5.9^{b} \pm 1.9$ & $6.2^{\mathrm{b}} \pm 1.7$ & $6.5^{\mathrm{ab}} \pm 1.8$ & $6.3^{\mathrm{ab}} \pm 1.5$ & $6.8^{\mathrm{ab}} \pm 1.8$ \\
\hline Texture & $7.5^{\mathrm{a}} \pm 1.2$ & $6.7^{b} \pm 1.5$ & $6.2^{\mathrm{b}} \pm 1.8$ & $6.3^{b} \pm 1.6$ & $6.6^{b} \pm 1.7$ & $6.3^{b} \pm 1.6$ & $6.7^{b} \pm 1.5$ \\
\hline Overall acceptance & $7.4^{\mathrm{a}} \pm 1.4$ & $6.5^{\mathrm{b}} \pm 1.5$ & $6.3^{\mathrm{b}} \pm 1.7$ & $6.4^{\mathrm{b}} \pm 1.5$ & $6.6^{b} \pm 1.5$ & $6.4^{\mathrm{b}} \pm 1.4$ & $6.9^{\mathrm{ab}} \pm 1.5$ \\
\hline Saltiness & $4.3^{\mathrm{a}} \pm 1.2$ & $3.6^{\mathrm{b}} \pm 1.1$ & $4.0^{\mathrm{ab}} \pm 1.3$ & $3.5^{b} \pm 1.1$ & $4.0^{\mathrm{ab}} \pm 1.1$ & $3.8^{\mathrm{b}} \pm 1.4$ & $3.9^{\mathrm{ab}} \pm 1.1$ \\
\hline Purchase intention & $3.9^{\mathrm{a}} \pm 1.1$ & $3.2^{\mathrm{b}} \pm 1.1$ & $2.9^{\mathrm{b}} \pm 1.2$ & $3.1^{b} \pm 1.2$ & $3.2^{\mathrm{b}} \pm 1.2$ & $3.0^{\mathrm{b}} \pm 1.1$ & $3.4^{\mathrm{ab}} \pm 1.2$ \\
\hline
\end{tabular}

$\mathrm{T} 1-10 \mathrm{~g} \mathrm{~kg}^{-1} \mathrm{NaCl}+5 \mathrm{~g} \mathrm{~kg}^{-1} \mathrm{KCl}+5 \mathrm{~g} \mathrm{~kg}^{-1} \mathrm{CaCl}_{2} ; \mathrm{T} 2-10 \mathrm{~g} \mathrm{~kg}^{-1} \mathrm{NaCl}+4.5 \mathrm{~g} \mathrm{~kg}^{-1} \mathrm{KCl}+4.5 \mathrm{~g} \mathrm{~kg}^{-1} \mathrm{CaCl}_{2} ; \mathrm{T} 3-10 \mathrm{~g} \mathrm{~kg}^{-1} \mathrm{NaCl}^{-} 4 \mathrm{~g} \mathrm{~kg}^{-1} \mathrm{KCl}+4 \mathrm{~g} \mathrm{~kg}^{-1} \mathrm{CaCl}_{2} ;$ $\mathrm{T} 4-10 \mathrm{~g} \mathrm{~kg}^{-1} \mathrm{NaCl}+3.5 \mathrm{~g} \mathrm{~kg}^{-1} \mathrm{KCl}+3.5 \mathrm{~g} \mathrm{~kg}^{-1} \mathrm{CaCl}_{2} ; \mathrm{T} 5-10 \mathrm{~g} \mathrm{~kg}^{-1} \mathrm{NaCl}+2.5 \mathrm{~g} \mathrm{~kg}^{-1} \mathrm{KCl}+2.5 \mathrm{~g} \mathrm{~kg}^{-1} \mathrm{CaCl}_{2} ; \mathrm{CH}-25 \mathrm{~g} \mathrm{~kg}^{-1} \mathrm{NaCl} ; \mathrm{Cl}-10 \mathrm{~g} \mathrm{~kg}{ }^{-1} \mathrm{NaCl}$.

Treatment $\mathrm{CH}$ is the standard for products available on the market, and treatment $\mathrm{T} 5$ showed higher flavor and texture scores compared to $\mathrm{CH}$. This shows that the addition of $0.25 \% \mathrm{KCl}+0.25 \% \mathrm{CaCl}_{2}$ under the proposed conditions were sufficient to mask the low $\mathrm{NaCl}$ content (1\%). In treatment $\mathrm{T} 5$, scores for flavor and texture were higher than those obtained by Campagnol et al. (2012) in a treatment with $50 \% \mathrm{Na}$ reduction and replacement with $\mathrm{KCl}$. OL obtained in our study was higher than that reported by Gimeno et al. (1998) for low sodium salami (formulation with $1 \% \mathrm{NaCl}, 0.55 \%$ $\mathrm{KCl}, 0.23 \% \mathrm{MgCl}_{2}$ and $0.46 \% \mathrm{CaCl}_{2}$ ) that obtained a 37 $\%$ lower OL. In our study with $\mathrm{Na}$ reduction, $\mathrm{T} 5$ salami had a $64 \% \mathrm{Na}$ reduction, resulting in a final $\mathrm{NaCl}$ content of $25 \mathrm{~g} \mathrm{~kg}^{-1}$ after a 28-d period of drying and ripening. Thus, since $\mathrm{Na}$ content in the products currently available in the market can be as much as $6000 \mathrm{mg} \mathrm{Na}$ $100 \mathrm{~g}^{-1}$ (Jiménez-Colmenero et al., 2001), the reduction in $\mathrm{NaCl}$ content in dried and fermented products remains the main challenge for laboratorial research.

To model consumer acceptance of the salami samples studied, a multivariate model called regression by partial least squares (PLS) was used. The PLS allowed for modelling consumer acceptance according to the instrumental measurements and the sensory attributes from the sensory descriptive analysis. This tool was also used by Toscas et al. (1999) to model consumer acceptance according to instrumental measurements of texture in meat.

In this research, only one PLS component was considered because the statistical $\mathrm{Q}^{2}$ did not increase significantly (Figure 2A), showing a value of 0.81 . This can be explained by how the first component commonly describes the behavior of most consumers, making the other components insignificant. According to Tenenhaus et al. (2005), the statistical $\mathrm{Q}^{2}$ is used to measure the importance of PLS components in predicting consumer acceptance of each sample by cross validation. On the other hand, the $R^{2} Y$ and $R^{2} X$ values represent the range of consumer acceptance and physicochemical characteristics according to the PLS component generated, representing 0.988 and 0.404 respectively. It indicates that the model was suitable for predicting consumer acceptance, based on a consideration of these three parameters.

Figure 2B presents the importance of each physicochemical property to the projection considering one component in the PLS. Attributes with a Variable Importance for the Projection (VIP) higher than 0.8 significantly contributed to the model projection (Wold, 1994). Then, the instrumental measurements that most contributed to the projection of the PLS were: texture, flavor, Aw 28 days, sodium, and Aw 0 day.

In Figure $2 \mathrm{C}$ it is shown that the predicted values and the observed experimental values were very similar. Thus the model was suitable for predicting consumer acceptance of salami according to sensory and physicochemical properties. The adequacy of the model was also confirmed by the low root-mean-squared-error (RMSE) and the high coefficient of determination $\left(\mathrm{R}^{2}\right)$.

The standardized coefficients are presented in Figure 2D, where on the $\mathrm{Y}$ axis, sensory and physicochemical properties that are in the positive range represent positive sensory attributes, while the physicochemical properties that were in the negative range on the $\mathrm{Y}$ axis represent negative sensory attributes for consumer acceptance of salami. The size of the columns indicates the influence of each attribute on consumer acceptance of the samples, be they positive or negative. Thus, the higher the column, the greater the influence of the descriptor on sample acceptance. Furthermore, it should be noted that if the standard deviation is crossing the $\mathrm{X}$ axis, the influence of the attribute cannot be considered with a $95 \%$ confidence interval (Gomes et al., 2014). Therefore, the most important measurements for predicting consumer acceptance of salami were: texture, flavor, Aw 28days, pH 60 h, sodium, and Aw 0 days.

\section{JAR scales}

The JAR scale is conventionally used to identify sensory attributes and to what extent a product "failed to deliver" its optimal condition. The implicit assumption is that the JAR scale can be used to "diagnose" the nature of a sensory problem and the approximate direction and magnitude for its correction (Rodríguez-García et al., 2014). The JAR results were analyzed by penalty analysis, relating the saltiness optimal level and its relation to OL. In this analysis, an attribute was considered significant when the correspondent percentage was higher than 20 (Xiong and Meullenet, 2006).

According to Figure 3, the reduction of OL related to the percentage of consumers in each treatment was described differently as regards the salt content using 

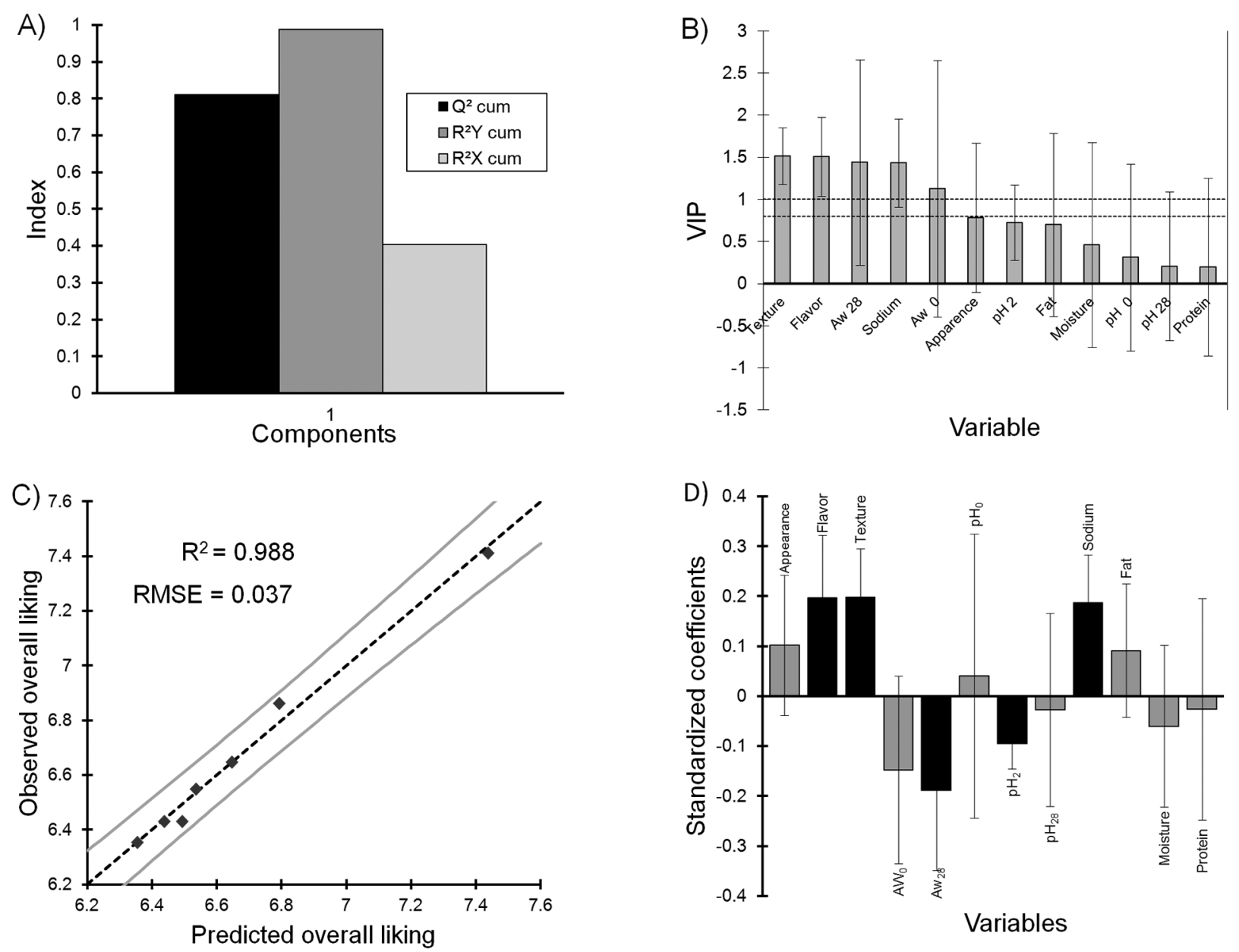

Figure 2 - Partial least squares (PLS) regression considering overall liking (OL) as a dependent variable and physicochemical and sensory parameters as independent variables. (A) Model quality by number of components; (B) Variable Importance in the Projection (VIP); (C) Observed OL vs Predicted OL; (D) Standardized coefficients (95\% of confidence interval).

the JAR scales. For most treatments, except for $\mathrm{CH}$ (with $25 \mathrm{~g} \mathrm{~kg}^{-1} \mathrm{NaCl}$ ), a content below the ideal causes a greater drop in acceptability. Conversely, a content above the ideal does not influence the reduction in acceptability (less than 1 point on a 9-point hedonic scale) strongly. This shows that the perception of saltiness below the ideal is a critical point and results in a reduction in acceptability of more than 1 point on a 9-point scale (Figure 3).

As regards salt content, consumers considered the $\mathrm{CL}$ treatment with a reduction in $\mathrm{NaCl}$ content without the addition of replacers $\left(\mathrm{KCl}\right.$ and $\left.\mathrm{CaCl}_{2}\right)$ as "less salty than the ideal" or "ideal". This is possibly because consumers of this type of product used amounts in excess of $1,600 \mathrm{mg} \mathrm{Na} 100 \mathrm{~g}^{-1}$, which is probably above the ideal.

Out of the two proposed extreme treatments /CL and $\mathrm{CH}$ ) in this study, $\mathrm{CH}$ was considered to have the ideal salt content and CL the lowest score regarding the ideal scale when compared with the other treatments. This shows that the reduction in $\mathrm{NaCl}$ in salami is a complex issue from the sensory point of view, because consumers seek a stronger salt taste and consider it a typical and striking characteristic of the product. When consumers choose the brand or type of salami to buy, they look for a product with stronger saltiness, which can be observed in this study due to high acceptability and the purchase intention score of $\mathrm{CH}$ (Figure 4), when $74 \%$ of consumers considered this salami to have the ideal amount of salt $(\mathrm{CH})$.

The penalty analysis applied to consumers and each sample provides information about the importance of salt. This should be considered as a basis for changes in product formulation to improve its acceptability. In treatments with salt replacers (T1, T2, T3, T4 and T5), 25 - $35 \%$ of consumers noticed differences from the ideal by more than one point on a scale of nine points and, it can be concluded that the replacers, in the amounts added, could not replace the intensity of salty taste which made consumers remain in doubt when it came to their buying intent of these salami. This can also be confirmed by the low purchase intention record- 

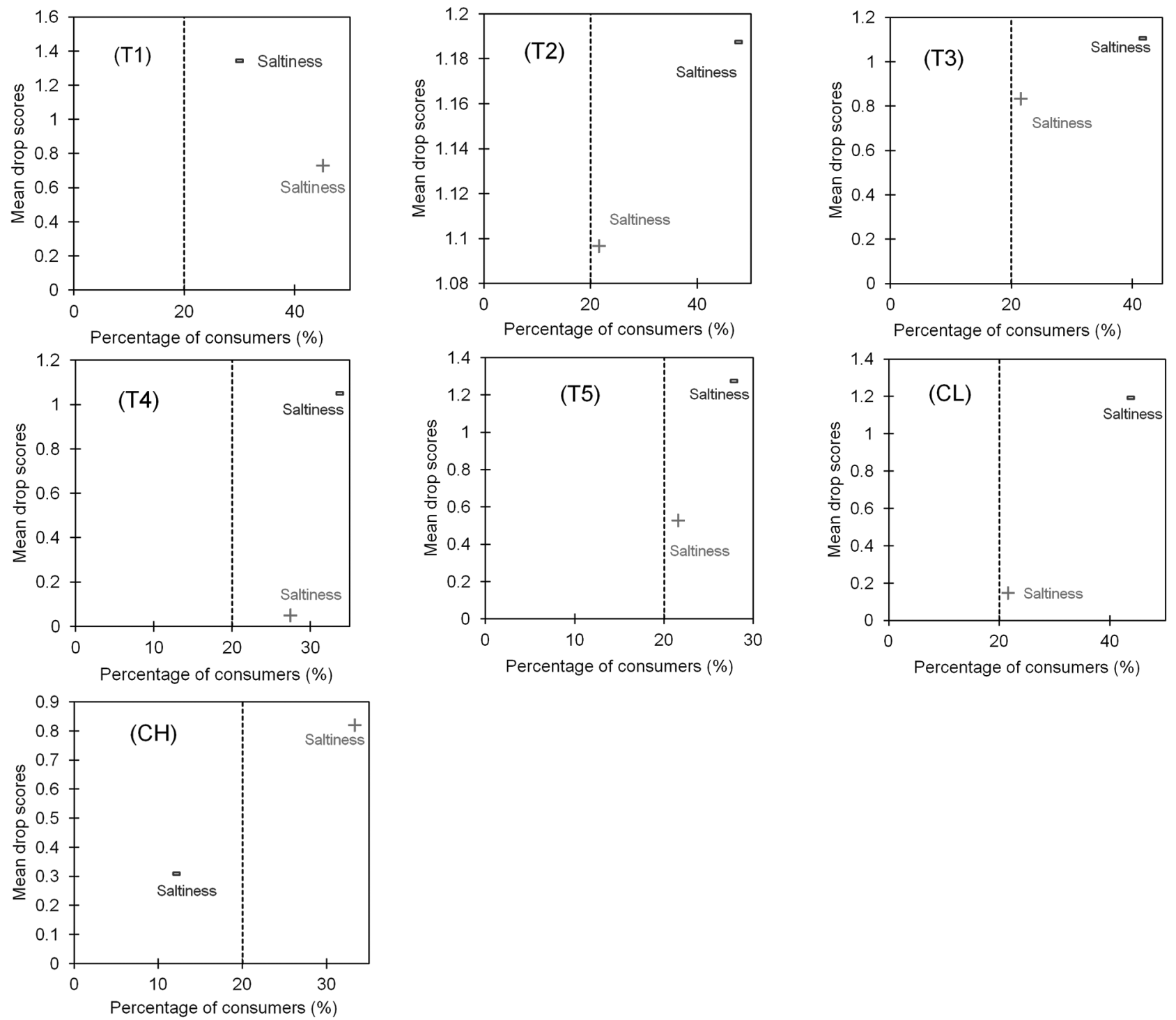

Figure 3 - Representation of drops on overall acceptance by a proportion of consumers using scales JAR (Just About Right); CL = Low Control, $\mathrm{CH}=$ High Control.

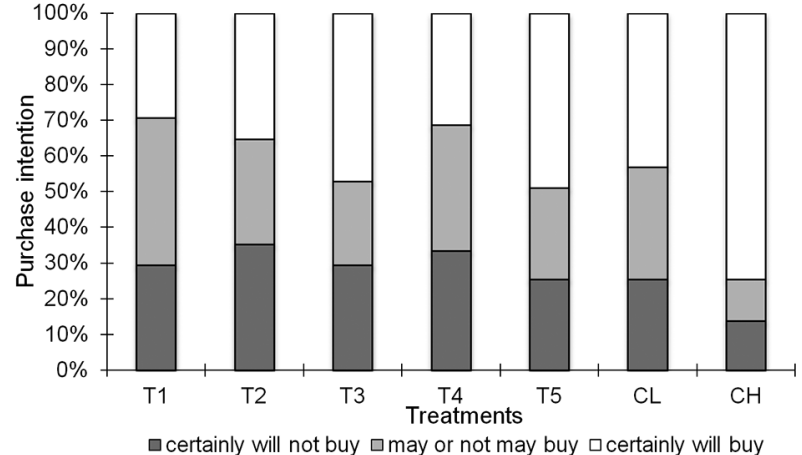

$\mathrm{T} 1-10 \mathrm{~g} \mathrm{~kg}^{-1} \mathrm{NaCl}+5 \mathrm{~g} \mathrm{~kg}^{-1} \mathrm{KCl}+5 \mathrm{~g} \mathrm{~kg}^{-1} \mathrm{CaCl}_{2} ; \mathrm{T} 2-10 \mathrm{~g} \mathrm{~kg}^{-1} \mathrm{NaCl}+4.5 \mathrm{~g} \mathrm{~kg}^{-1} \mathrm{KCl}+$ $4.5 \mathrm{~g} \mathrm{~kg}^{-1} \mathrm{CaCl}_{2} ; \mathrm{T} 3-10 \mathrm{~g} \mathrm{~kg}^{-1} \mathrm{NaCl}+4 \mathrm{~g} \mathrm{~kg}^{-1} \mathrm{KCl}_{2}+4 \mathrm{~g} \mathrm{~kg}^{-1} \mathrm{CaCl}_{2} ; \mathrm{T} 4-10 \mathrm{~g} \mathrm{~kg}^{-1} \mathrm{NaCl}$ $+3.5 \mathrm{~g} \mathrm{~kg}^{-1} \mathrm{KCl}+3.5 \mathrm{~g} \mathrm{~kg}^{-1} \mathrm{CaCl}_{2} ; 5-10 \mathrm{~g} \mathrm{~kg}^{-1} \mathrm{NaCl}+2.5 \mathrm{~g} \mathrm{~kg}^{-1} \mathrm{KCl}+2.5 \mathrm{~g} \mathrm{~kg}^{-1}$ $\mathrm{CaCl}_{2} ; \mathrm{CH}-25 \mathrm{~g} \mathrm{~kg}^{-1} \mathrm{NaCl} ; \mathrm{CL}-10 \mathrm{~g} \mathrm{~kg}^{-1} \mathrm{NaCl}$.

Figure 4 - Purchase intention of the tested products. ed for these treatments. Another point that should be considered is the type of formulation used. We opted for a heavier formulation of condiments and a greater use of lean meat, which is not a standard in this type of product. According to Campagnol et al. (2011a), the seasoning has a strong influence on the final results of salami with low sodium content.

According to our study, an alternative would be a small addition of chloride salts to be used as replacements $(0.25 \%$ each) combined with other technologies, namely greater flavoring (spices such as onion, garlic, cumin, paprika and others), new more proteolytic starter cultures (Leroy and De Vuyst, 2004), monosodium glutamate, disodium inosinate, disodium guanylate and amino acids (lysine and taurine) (Santos et al., 2014; Campagnol et al., 2011a; Campagnol et al., 2012), and yeast 
extract (Campagnol et al., 2011b). This could reduce Na content in salami but still yield a product with only $10 \mathrm{~g}$ $\mathrm{NaCl} \mathrm{kg} \mathrm{k}^{-1}$ of sample, which is acceptable to consumers at a relatively low cost. Moreover, other authors such as Guàrdia et al. (2006) have reported the viability of salami production with only $11 \mathrm{~g} \mathrm{NaCl} \mathrm{kg}^{-1}$ of sample.

\section{Conclusion}

This study allowed for salami to be produced with an $\mathrm{Na}$ reduction of $64 \%$ which was well accepted by consumers. The small addition of replacements showed sensory acceptability near to that of the product with $\mathrm{Na}$ content characteristic of commercial salami. The production of salami with only $1 \%$ of $\mathrm{NaCl}$ without the addition of replacements is viable; however, the consumer has a tendency to still look for saltier salami at the time of purchase.

\section{Acknowledgments}

This study was financially supported by the São Paulo Research Foundation (FAPESP) Project 2012/07113-2 and by Chr. Hansen, IBRAC and Sealed Air which supplied starter cultures, additives and packaging. Marcio Aurélio de Almeida thanks the Coordination for the Improvement of Higher Level Personnel (CAPES) for the scholarship. Erick Saldaña thanks the "Ministerio de Educación del Perú" for the scholarship granted by the "Programa Nacional de Becas y Crédito Educativo" (PRONABEC).

\section{References}

Agudelo, A.; Varela, P.; Fiszman, S. 2015. Fruit fillings development: a multiparametric approach. LWT - Food Science and Technology 61: 564-572.

Association of Official Analytical Chemists [AOAC]. 2005. Official Methods of Analysis of AOAC International. 18ed. Rockville, MD, USA.

Astiasarán, I.; Villanueva, R.; Bello, J. 1990. Analysis of proteolysis and protein insolubility during the manufacture of some varieties of dry sausage. Meat Science 28: 111-117.

Beriaín, M.J.; Peña, M.P.; Bello, J. 1993. A study of the chemical components which characterize Spanish saucisson. Food Chemistry 4: 31-37.

Blesa, E.; Aliño, M.; Barat, J.M.; Grau, R.; Toldrá, F.; Pagán, M.J. 2008. Microbiology and physico-chemical changes of drycured ham during the post-salting stage as affected by partial replacement of $\mathrm{NaCl}$ by other. Meat Science 78: 135-142.

Buckenhüskes, H.J. 1993. Selection criteria for lactic acid bacteria to be used as starter cultures for various food commodities. FEMS Microbiology Reviews 12: 253-272.

Cadena, R.S.; Cruz, A.G.; Rolim Netto, R.; Castro, W.F.; Faria, J.D.A.F.; Bolini, H.M.A. 2013. Sensory profile and physicochemical characteristics of mango nectar sweetened with high intensity sweeteners throughout storage time. Food Research International 54: 1670-1679.
Campagnol, P.C.B.; Santos, B.A.; Morgano, M.A.; Terra, N.N.; Pollonio, M.A.R. 2011a. Application of lysine, taurine, disodium inosinate and disodium guanylate in fermented cooked sausages with $50 \%$ replacement of $\mathrm{NaCl}$ by $\mathrm{KCl}$. Meat Science 87: 239-243.

Campagnol, P.C.B.; Santos, B.A.; Wagner, R.; Terra, N.N.; Pollonio, M.A.R. 2011b. The effect of yeast extract addition on quality of fermented sausages at low $\mathrm{NaCl}$ content. Meat Science 87: 290-298.

Campagnol, P.C.B.; Santos, B.A.; Terra, N.N.; Pollonio, M.A.R. 2012. Lysine, disodium guanylate and disodium inosinate as flavor enhancers in low-sodium fermented sausages. Meat Science 91: 334-338.

Choi, Y.M.; Jung, K.C.; Jo, H.M.; Nam, K.W.; Choe, J.H.; Rhee, M.S.; Kim, B.C. 2014. Combined effects of potassium lactate and calcium ascorbate as sodium chloride substitutes on the physicochemical and sensory characteristics of low-sodium frankfurter sausage. Meat Science 96: 21-25.

Cichoski, A.J.; Cansian, R.L.; Oliveira, D.; Gaio, I.; Saggirato, A.G. 2011. Lipid and protein oxidation in the internal part of Italian type salami containing basil essential oil (Ocimumbasilicum L.). Ciência e Tecnologia de Alimentos 31: 436-442.

Del Nobile, M.A.; Conte, M.; Incoronato, A.L.; Panza, O.; Sevi, A.; Marino, R. 2009. New strategies for reducing the pork back-fat content in typical Italian salami. Meat Science 81: 263-269.

Desmond, E. 2006. Reducing salt: a challenge for the meat industry. Meat Science 74: 188-196.

Fellendorf, S.; O'Sullivan, M.G.; Kerry, J.P. 2015. Impact of varying salt and fat levels on the physicochemical properties and sensory quality of white pudding. Meat Science 103: 75-82.

Gimeno, O.; Astiasarán, I.; Bello, J.A. 1998. Mixture of potassium, magnesium, and calcium chlorides as a partial replacement of sodium chloride in dry fermented sausages. Journal of Agricultural and Food Chemistry 46: 4372-4375.

Gomes, C.L.; Pflanzer, S.B.; Felício, P.E.; Bolini, H.M.A. 2014. Temporal changes of tenderness and juiciness of beef strip loin steaks. LWT - Food Science and Technology 59: 629-634.

Guàrdia, M.D.; Guerrero, L.; Gelabert, J.; Gou, P.; Arnau, J. 2006. Consumer attitude towards sodium reduction in meat products and acceptability of fermented sausages with reduced sodium content. Meat Science 73: 484-490.

International Organization for Standardization [ISO]. 2007. ISO 8589. Sensory Analysis: General Guidance for the Design of Test Rooms. International Organization for Standardization, Geneve, Switzerland.

Jiménez-Colmenero, F.; Carballo, J.; Cofrades, S. 2001. Healthier meat and meat products: their role as functional foods. Meat Science 59: 5-13.

Leroy, F.; De Vuyst, L. 2004. Lactic acid bacteria as functional starter cultures for the food fermentation industry. Trends in Food Science \& Technology 15: 67-78.

Leroy, F.; Verluyten, J.; Vuyst, L. 2006. Functional meat starter cultures for improved sausage fermentation. International Journal of Food Microbiology 106: 270-285.

Lücke, F.K. 1994. Fermented meat products. Food Research International 27: 299-307.

Meilgaard, M.; Civille, G.V.; Carr, B.T. 2006. Sensory Evaluation Techniques. 4ed. CRC Press, Boca Raton, FL, USA. 
Brasil. Ministério da Agricultura, Pecuária e Abastecimento 2000. Normative Instruction 22 dated 31 July 2000. Approves the identifying of technical regulations and quality of quality of salami. = Instrução Normativa $n^{\circ} 22$, de 31 de julho de 2000. Aprova o regulamento técnico de identidade de qualidade de salames. -Available at: http://extranet.agricultura.gov.br/ sislegis-consulta/servlet/VisualizarAnexo?id =1572 > [Accessed Dec. 1, 2014] (in Portuguese).

Popper, R. 2014. Use of Just-About-Right in consumer research. In: Varela, P.; Ares, G. Novel techniques in sensory characterization and consumer profiling. CRC Press, Boca Raton, FL, USA.

Quilaqueo, M.; Duizer, L.; Aguilera, J.M. 2015. The morphology of salt crystals affects the perception of saltiness. Food Research International 76: 675-681.

Ripollés, S.; Campagnol, P.C.B.; Armenteros, M.; Aristoy, M.C.; Toldrá, F. 2011. Influence of partial replacement of $\mathrm{NaCl}$ with $\mathrm{KCl}, \mathrm{CaCl} 2$ and $\mathrm{MgCl} 2$ on lipolysis and lipid oxidation in drycured ham. Meat Science 89: 58 - 64.

Rodríguez-García, J.; Salvador, A.; Hernando, I. 2014. Replacing fat and sugar with inulin in cakes: bubble size distribution, physical and sensory properties. Food and Bioprocess Technology 7: 964-974.

Ruusunen, M.; Puolanne, E. 2005. Reducing sodium intake from meat products. Meat Science 70: 531-541.

Santos, B.A.; Campagnol, P.C.B.; Morgano, M.A.; Pollonio, M.A.R. 2014. Monosodium glutamate, disodium inosinate, disodium guanylate, lysine and taurine improve the sensory quality of fermented cooked sausages with $50 \%$ and $75 \%$ replacement of $\mathrm{NaCl}$ with $\mathrm{KCl}$. Meat Science 96: 509-513.
Tenenhaus, M.; Pagès, J.; Ambroisine, L.; Guinot, C. 2005 PLS methodology to study relationships between hedonic judgements and product characteristics. Food Quality and Preference 16: 315-325.

Toldrá, F.; Nip, W.K.; Hui, Y.H. 2007. Dry fermented sausages: an overview. In Toldrá, F, Handbook of fermented meat and poultry. Blackwell, Oxford, UK.

Toscas, P.J.; Shaw, F.D.; Beilken, S.L. 1999. Partial least squares (PLS) regression for the analysis of instrument measurements and sensory meat quality data. Meat Science 52: 173-178.

World Health Organization [WHO]. 2012. Guideline: Sodium Intake for Adults and Children. World Health Organization, Geneva, Switzerland.

World Health Organization [WHO]. 2003. Diet, Nutrition and the Prevention of Chronic Diseases. World Health Organization, Geneva, Switzerland. (WHO Technical Reports Series, 916).

Wold, K.N.; MacGregor, J.F.; Dayal, B.; Wold, S. 1994. Multivariate design of process experiments [M-DOPE]. Chemometrics and Intelligent Laboratory Systems 23: 39-50.

Xiong, R.; Meullenet, J.F. 2006. A PLS dummy variable approach to assess the impact of jar attributes on liking. Food Quality and Preference 17: 188-198. 